\title{
AUNC
}

Zabytkoznawstwo i Konserwatorstwo XLVII

Toruń 2016

DOI: http://dx.doi.org/10.12775/AUNC_ZiK.2016.002

\section{Kontrakty z Janem Herberkiem, budowniczym i mieszczaninem kłodawskim na budowę kościoła Jezuitów w Grudziądzu (1646) oraz renowację zamku w Rogóźnie (1647)}

\section{BARTŁOMIEJ $Ł Y C Z A K$}

e-mail: blyczak@gmail.com

Keywords: architecture, Grudziądz, Jesuits, Rogóźno, Royal Prussia

Słowa kluczowe: architektura, Grudziądz, jezuici, Rogóźno, Prusy Królewskie

\begin{abstract}
Contracts with Jan Herberk, constructor and citizen of Kłodawa to build a Jesuit church in Grudziądz (1646) and renovate the castle in Rogóźno (1647) The article discusses two contracts concluded in years 1646 and 1647 by Jan Herberk, constructor and citizen of Kłodawa. The first document concerns building of a Jesuit church in Grudziądz. It was signed on 2 August 1646, and the commission came from Jan Działyński (1590-1648), starosta of Puck, Rogoźno and Pokrzywno, known for many sacral donations. He undertook to cover the costs of the construction of the church, estimated on 15.000 polish zloty, and to deliver all the necessary building materials. Herberk was obliged to finish his works - along with covering the roof with tiles and constructing six tombs inside the church - in span of two years. Unfortunately, only a part of foundations was laid and soon the works were abandoned. Due to prolonged unstable times of war, the construction was not resumed until 1682 (this time in a different location), most probably without Herberk's participation, and the church was finally consecrated in 1721 .

On 1 July 1647 Herberk signed another contract, this time to renovate the castle in Rogóźno. It was built by the Teutonic Order before 1285 and after being taken over by the Kingdom of Poland in 1644 it gradually fell into ruin. Władysław Konstanty
\end{abstract}


Wituski (1603-1655), the administrator of the castle in years 1647-1652, ordered a complex restoration of the building. Unfortunately, the range of eventually executed works is not known. According to descriptions from the fourth quarter of the seventeenth century, the castle was at that time almost completely ruined.

Jan Herberk, the architect form Kłodawa, was hitherto unknown. An attempt to find some more information on him in archival documents has not brought any positive results. The existing literature does however mention a builder named Jan Herbek. He was active since 1615 in Szydłowiec, at the time a lively centre of stonemasonry. He also worked in Warsaw (1636) and Kielce, where he built the castle of bishops of Kraków (1637-1644) and - possibly - the church of Holy Trinity (1644-1646). His ties with Kłodawa are not known, so despite resembling names he cannot be definitely identified with the constructor working for Jesuits in Grudziądz and renovating the castle in Rogóźno.

\begin{abstract}
Abstrakt
W artykule omówione zostały dwa kontrakty zawarte w latach 1646-1647 przez Jana Herberka, budowniczego i obywatela Kłodawy. Pierwszy z nich dotyczy budowy kościoła jezuickiego w Grudziądzu. Umowa podpisana została 2 VIII 1646 r., a zleceniodawcą prac był Jan Działyński (1590-1648), starosta pucki, rogoziński i pokrzywnicki, znany z licznych fundacji sakralnych. Zobowiązał się on do pokrycia kosztów wystawienia świątyni jezuickiej oszacowanych na $15.000 \mathrm{złp} \mathrm{oraz} \mathrm{dostarczenia} \mathrm{wszelkich}$ potrzebnych materiałów budowlanych. Herberk miał zakończyć prace w ciągu dwóch lat wraz z pokryciem świątyni dachówką oraz wymurowaniem wewnątrz sześciu grobów. Niestety zdążono położyć jedynie część fundamentów kościoła i wkrótce budowę wstrzymano. Przeciągający się okres niepokojów wojennych spowodował, że roboty wznowiono dopiero w 1682 r., zapewne już bez udziału Herberka. Zmieniono przy tym lokalizację świątyni, którą ostatecznie konsekrowano dopiero w $1721 \mathrm{r}$.

Dnia 1 VII 1647 r. Herberk podpisał kontrakt na renowację zamku w Rogóźnie. Wybudowany został on przed 1285 r., a po przejściu w ręce polskie w 1466 r. na skutek różnych czynników popadał stopniowo w ruinę. Administrujący zamkiem w latach 1647-1652 ekonom rogoziński Władysław Konstanty Wituski (1603-1655) zlecił kompleksowe odnowienie jego bryły wraz z pokryciem dachowym i robotami wykończeniowymi. Niestety zakres ostatecznie zrealizowanych prac nie jest dziś znany; według opisów z 4 ćwierci XVII w. budowla była wówczas niemal zupełnie zrujnowana.

Postać Jana Herberka, budowniczego z Kłodawy, nie była dotąd znana, zaś próba odnalezienia bliższych informacji źródłowych na jego temat nie przyniosła pozytywnych rezultatów. W literaturze notowany jest murator Jan Herbek, działający w 1 połowie XVII w. Aktywny był on od 1615 r. w Szydłowcu, w tym okresie stanowiącym prężne centrum kamieniarskie. Działał także w Warszawie (1636) oraz Kielcach, gdzie powierzono mu budowę pałacu biskupów krakowskich (1637-1644) oraz - być może - kościoła pw. Świętej Trójcy (1644-1646). Nie są jednak udokumentowane żadne jego związki z Kłodawą, więc pomimo zbieżności nazwisk nie można ostatecznie utożsamić go z kierownikiem prac budowlanych dla jezuitów w Grudziądzu oraz odnową zamku w Rogóźnie.
\end{abstract}


Epoka nowożytna w Rzeczypospolitej obfitowała w nowe realizacje architektoniczne. Mnogość nowo powstających budowli o religijnym oraz świeckim przeznaczeniu powodowała duże zapotrzebowanie na architektów i kierowników robót. Badacze tematu najwięcej uwagi poświęcają - co oczywiste jednostkom wyróżniającym się talentem artystycznym bądź organizacyjnym. Na gruncie mniej prestiżowych zleceń starali się z nimi konkurować także prowincjonalni budowniczowie, o lokalnej sławie. Jednym ze słabo dotąd rozpoznanych architektów był działający w połowie XVII wieku Jan Herberk, obywatel Kłodawy. W niniejszym opracowaniu krótko omówione zostaną dwa zawarte przez niego kontrakty. Pierwszy, z 1646 roku, dotyczący budowy kościoła dla grudziądzkich jezuitów, został odnaleziony w trakcie kwerendy w Archiwum Państwowym w Toruniu w niewielkim, bo liczącym zaledwie pięć jednostek zespole „Akta klasztoru OO. Jezuitów w Grudziądzu”. Natomiast spisana w 1647 roku umowa w sprawie renowacji zamku w Rogóźnie jest przechowywana w Szwedzkim Archiwum Narodowym, w zbiorach Skokloster ${ }^{2}$. Oba dokumenty - przytoczone w pełnym brzmieniu w aneksach - stanowią ciekawe uzupełnienie wiedzy na temat lokalnego krajobrazu architektonicznego w Grudziądzu i najbliższych okolicach.

Dzieje budowy kościoła jezuickiego w Grudziądzu nie doczekały się dotychczas szczegółowego opracowania naukowego. W literaturze przedmiotu informacje na ten temat są przeważnie powtarzane za publikacjami z XIX i początku XX wieku: monografią miasta przygotowaną przez Xavera Froelicha oraz syntezą dziejów jezuitów w Polsce autorstwa Stanisława Załęskiego ${ }^{3}$. Zdecydowana większość źródeł archiwalnych dotyczących Grudziądza - zarówno akta miejskie, jak i kościelne - została zniszczona lub zaginęła

Archiwum Państwowe w Toruniu, Akta klasztoru OO. Jezuitów w Grudziądzu, sygn. 5, s. 49-50, Kontrakt z architektem na fabrykę kościoła grudziądzkiego Societatis Jesu Anno Domini 1646; por. Aneks 1.

2 Riksarkivet, Stockholm, Skoklostersamlingen, sygn. E8602, [Kontrakt między Władysławem Konstantym Wituskim a Janem Herberkiem na prace remontowe w zamku w Rogóźnie z 1 lipca 1647 r.], http://www.repcyfr.pl/dlibra/doccontent?id=997\&dirids=1 (dostęp 20 września 2016); por. Aneks 2.

3 Xaver Froelich, Geschichte des Graudenzer Kreises, t. 1 Die allmälige Gestaltung der Grundverhältnisse und Besitzrechte, die Entstehung, Bevölkerung, Verwaltung und Zusammengehörigkeit der Kreis-Ortschaften, die Entwicklung des städtischen und ländlichen Kommunalwesens, der Adelsrechte, des Steuer-, Militair-, Kirchen- und Schulwesens und der Justizverfassung (Graudenz: Selbstverlage, 1868); Stanisław Załęski, Jezuici w Polsce, t. 4, cz. 3 Kolegia i domy założone w drugiej dobie rządów Zygmunta III i za rządów Władysława IV: 1608-1648 (Kraków: Druk. W. L. Anczyca, 1905), 1211-1224. 
w wyniku drugiej wojny światowej. Dlatego też interesująco przedstawia się zamieszczona w poświęconej temu miastu popularnonaukowej publikacji Tadeusza Chrzanowskiego wzmianka o kontrakcie na budowę kościoła zawartym w 1646 roku z Janem Herberkiem, mieszczaninem kłodawskim ${ }^{4}$. Niestety książka jest pozbawiona jakichkolwiek wskazówek bibliograficznych oraz przypisów, nie wiadomo zatem, skąd autor zaczerpnął wiedzę na temat tej umowy. Informacja została powtórzona w przewodniku po mieście z 1974 roku, opracowanym przez Janusza Umińskiego, oraz w nielicznych późniejszych tekstach ${ }^{5}$. Co ciekawe, pominięto ją w zeszycie Katalogu zabytków sztuki w Polsce odnoszącym się do powiatu grudziądzkiego, wydanym w 1974 roku$^{6}$.

Umowa dotycząca budowy kościoła jezuickiego została zawarta 2 sierpnia 1646 roku. Zleceniodawcą prac był Jan Działyński, starosta pucki, rogoziński i pokrzywnicki. Koszt wzniesienia świątyni, wraz z zakrystią i „sklepikiem do zakrystii należącym”, wyceniony został na piętnaście tysięcy złotych polskich. Zapewnienie wszelkich materiałów, zarówno niezbędnych, czyli cegły, kamienia, wapna, gwoździ, zawiasów, rusztowań oraz innych, jak i - zależnie od życzenia zleceniodawcy - bardziej dekoracyjnych: ozdobnych kapiteli, tympanonów, gzymsów, leżało w gestii fundatora. Jan Herberk ze swojej strony zobowiązał się ukończyć budowę w ciągu dwóch lat, wraz z pokryciem świątyni dachówką, wymurowaniem wewnątrz sześciu grobów, otynkowaniem i wybieleniem całości oraz wykonaniem dekoracji sklepienia. Miał on opłacić ze swojego wynagrodzenia wszelkich czeladników i pomocników, z wyjątkiem cieśli przygotowującego więźbę dachową, którego zatrudnienie należało do fundatora.

W kontrakcie dwukrotnie wzmiankowano załączony do niego projekt świątyni, zatwierdzony przez Działyńskiego („wizerunek podany”, „abrys podany ścian”). Szkic ten nie został dotąd zidentyfikowany, nie ma informacji, kto był jego autorem. Hipotetycznie można założyć, że wykonał go Herberk, określany w umowie jako architekt. Z drugiej strony jego zadania mogły się ograniczać

\footnotetext{
Tadeusz Chrzanowski, Grudziądz (Warszawa: „Sport i Turystyka”, 1970), 9.

5 Janusz Umiński, Grudziądz. Przewodnik (Warszawa: „Sport i Turystyka”, 1974), 41; Barbara Janiszewska-Mincer, „Grudziądz w latach 1064-1772”, w Dzieje Grudziądza, t. 1 Do roku 1920, red. Jerzy Danielewicz (Grudziądz: Grudziądzkie Towarzystwo Kultury, 1992), 244; Agnieszka Zawadka, „Nowożytne zabytki epigraficzne kościoła pw. św. Franciszka Ksawerego w Grudziądzu”, Rocznik Grudziądzki 15 (2003): 225.

6 Ryszard Brykowski i Teresa Żurkowska, „Powiat grudziądzki”, w Katalog zabytków sztuki w Polsce, t. 11, z. 7 (Warszawa: IS PAN, 1974), 17-19.
} 
do skompletowania odpowiednich pracowników warsztatowych oraz nadzorowania robót budowlanych, co było w owym czasie częstą praktyką.

Jak wynika z zamieszczonych pod tekstem kontraktu dopisków, wkrótce po jego podpisaniu rozpoczęto budowę świątyni. Te w dużej mierze nieczytelne adnotacje zawierają wykaz kilku płatności, z których ostatniej dokonano 15 września - zapewne 1647 roku? $^{7}$.

Według przekazów znanych z dawnej literatury w pierwszej fazie budowy udało się położyć jedynie część fundamentów, dalsze roboty zostały wkrótce przerwane. Powodem była z pewnością śmierć Działyńskiego (11 marca 1648 r.) i proces wytoczony jezuitom przez rodzinę zmarłego, która próbowała anulować wszelkie jego fundacje na rzecz grudziądzkiego zakonu i przejąć cały majątek8. Ówczesny rektor Daniel Siekierzecki $\left(1648-1652^{9}\right)$ za najważniejsze zadanie uznał otwarcie kolegium. W rezultacie budowa kościoła została wstrzymana na długie lata, naznaczone przeciągającymi się konfliktami: powstaniem Chmielnickiego oraz szczególnie dotkliwymi dla Grudziądza działaniami Szwedów podczas drugiej wojny północnej ${ }^{10}$. Rozkradzione wtedy zostały wszelkie zgromadzone materiały budowlane - drewno, wapno i cegły ${ }^{11}$. Gdy w 1682 roku ruszyły na nowo prace wokół świątyni, zdecydowano się zmienić jej lokalizację i położono nowe fundamenty pod nawę główną w miejscu dzisiejszego kościoła ${ }^{12}$. Według Tadeusza Chrzanowskiego w kolejnych etapach budowy nie uczestniczył już Jan Herberk, który miał umrzeć wkrótce po rozpoczęciu prac - informacja ta nie znalazła jednak dotąd potwierdzenia w źródłach. Po wznowieniu robót kierować miał nimi Jan Pade $^{13}$; należy go najpewniej wiązać z jezuitą o tym nazwisku, rektorem gru-

Zapiski pozbawione są dat rocznych.

Załęski, Jezuici, 1214.

9 „Siekierzecki, Daniel”, w Encyklopedia wiedzy o jezuitach na ziemiach Polski i Litwy 1564-1995, oprac. Ludwik Grzebień przy współpr. zespołu jezuitów (Kraków: Wydawnictwo WAM, 2004), 615.

10 Załęski, Jezuici, 1218-1219; Janiszewska-Mincer, „Grudziądz”, 220-222.

11 Informuje o tym cytowany przez X. Froelicha dokument z 1715 r., odnaleziony w kuli umieszczonej na szczycie grudziądzkiego kościoła po jego ostatecznym ukończeniu - Froelich, Geschichte, 120.

12 Załęski, Jezuici, 1215; Froelich, Geschichte, 120-121; Bolesław Makowski, Sztuka na Pomorzu: jej dzieje i zabytki (Toruń: Kasa im. Mianowskiego; Warszawa: Instytut Popierania Nauki, 1932), 138.

13 Chrzanowski, Grudziądz, 9. Informację tę powtórzyli także inni autorzy piszący o kościele jezuickim: Umiński, Grudziądz, 41; Janiszewska-Mincer, „Grudziądz”, 244; Zawadka, „Nowożytne zabytki”, 225. 
dziądzkiego kolegium w latach $1684-1687^{14}$. Jego zadania polegały raczej na nadzorowaniu budowy i zabezpieczeniu finansowej strony przedsięwzięcia. Wkrótce ze względu na brak funduszy prace ponownie przerwano, dopiero w 1699 roku dzięki donacji Tomasza Działyńskiego rozpoczęto stawianie murów. Wypadki trzeciej wojny północnej ponownie wymusiły zaniechanie budowy. Bryłę kościoła ukończono ostatecznie w latach $1713-1715^{15}$, następnie zajęto się wykończeniem wnętrza i jego wyposażaniem. Konsekracja świątyni nastąpiła w 1721 roku.

Jak wspomniano, wszelkie prace budowlane zlecił i zobowiązał się opłacić Jan Działyński herbu Ogończyk (1590-1648) ${ }^{16}$, syn Stanisława i Heleny z Plemięckich. Duży wpływ na rozwój kariery tego cenionego w Prusach Królewskich polityka miała działalność wojskowa - brał udział w wojnach z Turcją, Rosją i Szwecją, w tym w bitwie pod Chocimiem (1621). Należały do niego starostwa: pokrzywnickie (1617-1647), rogozińskie (od 1626 r.), puckie (od 1627 r.) i kowalewskie (od 1647 r.). W roku 1647 został wybrany na urząd wojewody chełmińskiego. Od 1620 roku brał udział w sejmach, wielokrotnie pełnił funkcję marszałka sejmików pruskich. Był rzecznikiem przywilejów rodzimej prowincji, dążył przy tym do ograniczenia znaczenia wielkich miast pruskich, szczególnie ostro atakował Gdańsk i Toruń.

Działyński ukończył kolegium jezuickie w Braniewie i znany był jako gorliwy katolik, który przeznaczał sporo sił i środków finansowych na rzecz Kościoła. Na sejmach występował z żądaniami gwarancji wyznaniowych dla katolików w wielkich miastach pruskich. Aktywnie działał także na polu fundacji sakralnych. W farze pw. św. Mikołaja w Grudziądzu wzniósł ośmioboczną kaplicę rodową (1620-1624), w której został pochowany, i opłacił budowę kruchty od strony południowej $(1632)^{17}$. Sfinansował ponadto odnowienie świątyń w Okoninie (przed 1640 r.), Dąbrówce Królewskiej (przed 1647 r.),

14 Jan Pade żył w latach 1624-1693. „Pade, Jan”, w Encyklopedia wiedzy, 488.

15 X. Froelich wzmiankował znany mu kontrakt z 24.01.1714 r. z cieślą nazwiskiem Fickel, który miał wykonać pokrycie dachowe świątyni - Froelich, Geschichte, 120.

16 Krótki biogram J. Działyńskiego za: Herbarz polski Kaspra Niesieckiego S.J. Powiększony dodatkami z poźniejszych autorów, rękopismów, dowodów urzędowych, wyd. Jan Nepomucen Bobrowicz, t. 3 (Lipsk: nakładem i drukiem Breitkopfa i Hærtela, 1839), 453-454; Stanisław Bodniak, „Działyński, Jan”, w Polski słownik biograficzny, t. 6 (Kraków: PAU; Wrocław: Ossolineum, 1948), 83-84; Jarosław Porazinski, „Działyński, Jan”, w Słownik biograficzny Pomorza Nadwiślańskiego, t. 1 (Gdańsk: Wydawnictwo Gdańskie, 1992), 366.

17 Brykowski i Żurkowska, „Powiat grudziądzki”, 7. 
Rogóźnie (1647) i Ryńsku (1648) ${ }^{18}$. Miał także niewątpliwe zasługi dla powstania kolegium jezuitów w Grudziądzu, gdyż ofiarował na ten cel wykupione przez siebie parcele w mieście ${ }^{19}$. Kościół wspierała również druga małżonka Działyńskiego, Justyna z domu Knut, wdowa po Ludwiku Mortęskim, która ufundowała i uposażyła grudziądzki konwent benedyktynek $(1631)^{20}$.

Stan badań nad nowożytnymi losami zamku krzyżackiego w Rogóźnie prezentuje się niezwykle skromnie. Najważniejszym opracowaniem pozostaje do dziś artykuł Marii Rzeczkowskiej-Sławińskiej zamieszczony w 1970 roku w „Roczniku Grudziądzkim”21. Tekst ten zawiera podsumowanie badań publikowanych przez autorów niemieckich oraz nowe ustalenia, oparte na wynikach prac wykopaliskowych i niewykorzystywanych wcześniej źródłach. Późniejsze, popularne opracowania w zasadzie nie wniosły do tematu nic nowego ${ }^{22}$.

Murowany zamek konwentualny w Rogóźnie powstał krótko przed rokiem 1285, kiedy odnotowano miejscowego komtura ${ }^{23}$. Po drugim pokoju toruńskim w 1466 roku przeszedł w ręce polskie: początkowo był siedzibą starostwa rogozińskiego, a od 1590 roku stał się ekonomią królewską. Według dawnych przekazów już w drugiej połowie XVI wieku zamek był mocno zniszczony w wyniku licznych pożarów i osuwania się zbocza. W roku 1628 król szwedzki Gustaw Adolf wydał rozkaz wysadzenia części murów dla wypróbowania nowego typu min. Z czasem budowla coraz bardziej niszczała, mimo podejmowanych przez kolejnych zarządców doraźnych napraw. Według opisów z lat 1675 i 1686 zamek był już wówczas niemal zupełnie zrujnowany, w dobrym stanie utrzymała się natomiast część zabudowań gospodarczych na przedzamczu. Po przejściu tych ziem pod pruskie panowanie w 1772 roku

18 Brykowski i Żurkowska, „Powiat grudziądzki”, 3, 48, 55; Tadeusz Chrzanowski i Marian Kornecki, „Powiat wąbrzeski”, w Katalog zabytków sztuki w Polsce, t. 11, z. 19 (Warszawa: IS PAN, 1967), 35.

19 Hugo Manstein, red., Die Annalen der Stadt Graudenz von 1563 bis 1660 (Graudenz: Gustav Röthes Buchdruck, 1904), 64.

20 Brykowski i Żurkowska, „Powiat grudziądzki”, 12-13.

21 Maria Rzeczkowska-Sławińska, „Zamek pokrzyżacki w Rogoźnie (powiat grudziądzki)”, Rocznik Grudziądzki 5-6 (1970): 71-96 - tam zestawienie wcześniejszej literatury.

22 Ryszard Boguwolski i Andrzej Kola, Zamek pokrzyżacki w Rogóźnie (Rogoźno: Urząd Gminy; Grudziądz: Muzeum, 1997); Andrzej Pabian i Waldemar Rozynkowski, Zamki krzyżackie na ziemi chełmińskiej (Toruń: Wydawnictwo Naukowe „Scriptor M\&A”, 1997), 95-100; Ryszard Boguwolski i Lothar Hyss, Zamki krzyżackie powiatu grudziądzkiego (Grudziądz: Muzeum, 2004), 46-57.

${ }^{23}$ Krótka historia zamku za: Rzeczkowska-Sławińska, „Zamek pokrzyżacki”, 74-79; Brykowski i Żurkowska, „Powiat grudziądzki”, 57-60. 
zamek rozebrano w celu pozyskania budulca dla twierdzy w Grudziądzu. Dziś po całym założeniu pozostały jedynie fragmenty, częściowo odnowione w XX wieku: wysoka wieża bramna przedzamcza wewnętrznego, elementy fundamentów i murów oraz pojedyncze budynki gospodarcze na przedzamczu, pochodzące z różnych okresów.

Renowacja budowli w połowie XVII wieku nie była dotąd omawiana, nie wzmiankowano także umowy na prace remontowe prowadzone przez Jana Herberka. Zlecił je ekonom rogoziński Władysław Konstanty Wituski herbu Gozdawa (1603-1655), zarządzający zamkiem w imieniu króla ${ }^{24}$. Urodził się on w niewielkiej mazowieckiej miejscowości Zyck (obecnie Zyck Polski, pow. płocki) jako syn stolnika gostyńskiego Jana Wituskiego i Anny z Małachowskich. Wiadomo, że w 1633 roku Wituski udał się do Niderlandów (Amsterdam, Lejda, Haga), aby uczyć się wojennego rzemiosła. Po rocznym tam pobycie wyruszył do Brazylii, gdzie brał udział w walkach u boku Krzysztofa Arciszewskiego. W roku 1636 lub 1637 wrócił do Polski i rozpoczął karierę polityczną. Kilkakrotnie posłował na sejm, po raz pierwszy w 1639 roku; posługiwał się już wówczas tytułem dworzanina pokojowego króla Władysława IV. Był kolejno chorążym (1640) i podkomorzym gostyńskim (1650). Jako ekonom rogoziński administrował zamkiem w latach 1647-165225. W 1640 roku poślubił Annę Parzniewską.

Kontrakt między Wituskim a Janem Herberkiem został podpisany 1 lipca 1647 roku. Nie sprecyzowano w nim daty ukończenia prac restauracyjnych ani nie wpisano w odpowiednim miejscu kwoty wynagrodzenia. Pod tekstem dokumentu wyszczególniono jedynie produkty spożywcze, które miał otrzymać Herberk z pomocnikami. Do najważniejszych zadań budowniczego należało kompleksowe odnowienie bryły zamku, od fundamentów i murów po przykrycie całości dachówką, wymurowanie dwóch narożnych alkierzy oraz roboty wykończeniowe: wstawienie okien i drzwi, wyłożenie posadzek w pokojach itp., ze szczególnym wskazaniem na potrzebę prac w kuchni na pierwszym piętrze oraz znajdującej się nad nią jadalni. Należało także wymienić pokrycie dachowe w „wieży wielkiej” oraz wymurować schody według

24 Informacje o W. K. Wituskim za: Władysław Czapliński, „Władysław Konstanty Wituski, żołnierz kolonialny w XVII w.”, Rocznik Gdański. Organ Towarzystwa Przyjaciół Nauki i Sztuki w Gdańsku 11 (1937): 163-176; „Wituski, Władysław Konstanty”, w Zdzisław Malczewski, Słownik biograficzny Polonii brazylijskiej (Warszawa: Centrum Studiów Latynoamerykańskich - Uniwersytet Warszawski, 2000), 202.

25 Rzeczkowska-Sławińska, „Zamek pokrzyżacki”, 77, przypis 30. 
przedstawionego projektu. Wszelkie materiały budowlane - podobnie jak w przypadku robót przy kościele jezuickim w Grudziądzu - dostarczyć miał na swój koszt zleceniodawca prac. W jego gestii pozostawało również zatrudnienie ludzi do odgruzowania wnętrz wraz z piwnicami oraz ewentualnego kopania fundamentów.

Zakres wykonanych robót nie jest dziś znany - brakuje przekazów ikonograficznych i szczegółowych opisów zamku z około 1650 roku, zanim został ponownie zniszczony w drugiej połowie XVII wieku i ostatecznie rozebrany na rozkaz władz pruskich. Być może zostały położone nowe podłogi, gdyż w opisie dóbr rogozińskich z 1675 roku odnotowano, że „ostatek posadzki niepotłuczony” z pokojów przeniesiono do zamku w Grudziądzu ${ }^{26}$.

Jan Herberk - architekt z Kłodawy pozostaje do dziś enigmatyczną postacią. Jego nazwisko nigdzie indziej, poza wymienionymi tu kontraktami, się nie pojawia. Kwerenda w aktach metrykalnych katolickiej parafii w Kłodawie, przechowywanych w Archiwum Diecezjalnym we Włocławku, nie przyniosła rezultatów. Najstarsza zachowana księga zawiera spis chrztów od roku 1656 oraz zaślubin dla lat $1668-1678^{27}$.

W literaturze przedmiotu notowany jest natomiast Jan Herbek, murator działający w pierwszej połowie XVII wieku. Wiadomo, że w 1615 roku poślubił w Szydłowcu Barbarę Sierpieniową, z którą miał córkę Zofię, ochrzczoną tamże 4 maja 1616 roku $^{28}$. Szydłowiec, pod panowaniem Radziwiłłów przeżywający okres największego rozkwitu, był wówczas ważnym ośrodkiem kamieniarskim. W pierwszej tercji stulecia wzmiankowano tam aż trzynastu muratorów, spośród których najbardziej znani byli pochodzący z Włoch Albert i Kacper Fodyga ${ }^{29}$. Pierwszy z nich - co warto nadmienić: ojciec chrzestny Zofii Herbek - zasiadał nawet w tamtejszych władzach miejskich ${ }^{30}$.

26 Archiwum Państwowe w Toruniu, Akta miasta Torunia, kat. II, sygn. XIV-37, [Opis dóbr ekonomii Rogozińskiej, 1675], k. 3v-4.

${ }_{27}$ Archiwum Diecezjalne we Włocławku, Akta metrykalne, Kłodawa, sygn. 1b, [Spis chrztów z lat 1656-1684 oraz ślubów z lat 1668-1678 i 1684].

28 Feliks Kiryk, „Przyczynki do dziejów Szydłowca w pierwszej połowie XVII stulecia”, w Cała historia to dzieje ludzi... Studia z historii społecznej ofiarowane Profesorowi Andrzejowi Wyczańskiemu w 80-tą rocznicę urodzin i 55-lecie pracy naukowej, red. Cezary Kukla (Białystok: Wydawnictwo Uniwersytetu w Białymstoku, 2004), 245-246.

29 Aistė Paliušytė, „Fodyga, Casper”, w Allgemeines Künstlerlexikon. Die bildenden Künstler aller Zeiten und Völker, t. 41 (München-Leipzig: K. G. Saur, 2004), 436-437.

30 Kiryk, „Przyczynki”, 245. 
Znany jest szereg prac zrealizowanych przez Jana Herbka w Szydłowcu. W 1624 roku był zatrudniony na zamku, w latach 1628-1629 przy „zasklepieniu i zawarciu" ratusza ${ }^{31}$. Wykonał epitafium Benedykta Protasowicza (zm. 1624 r.) oraz nadzorował prace remontowe przy oknach w farze pw. św. Zygmunta. W 1632 roku zajmował się robotami kamieniarskimi na zlecenie dworu królewskiego, cztery lata później był uchwytny również w Warszawie ${ }^{32}$. Stamtąd już w następnym roku został wezwany do Kielc, gdzie na zlecenie biskupa Jakuba Zadzika kierował budową pałacu biskupów krakowskich (ukończonego w 1644 r.) oraz - być może - kościoła pw. Świętej Trójcy (około lat1644-1646) $)^{33}$. Dalsze losy Herbka nie są znane. Bez wątpienia jego dokonania w zakresie budownictwa i kamieniarstwa prezentują się niezwykle ciekawie, zatrudniali go najpotężniejsi fundatorzy, z dworem królewskim i biskupem krakowskim na czele.

Czy ów Jan Herbek mógł być tożsamy z pierwszym budowniczym grudziądzkiego kościoła oraz kierownikiem prac remontowych w zamku rogozińskim? Ku takiej hipotezie skłania niewątpliwa zbieżność nazwiska oraz profesji, a także czas podpisania kontraktu na wystawienie jezuickiej świątyni - bezpośrednio po zakończeniu przypisywanych mu prac przy kościele pw. Świętej Trójcy w Kielcach. Nie udokumentowano jednak związków Jana Herbka z Kłodawą: dotychczas łączono go raczej z Szydłowcem, gdzie był uchwytny najdłużej. Znane realizacje tego mistrza były przy tym bardziej prestiżowe niż zlecenia w Grudziądzu i Rogóźnie. Pozostaje zatem liczyć na odnalezienie kolejnych źródeł archiwalnych, które pozwolą na pełniejsze rozpoznanie życia i twórczości budowniczego Jana Herberka.

31 Krzysztof Dumała, „Przyczynek do dziejów kamieniarstwa w Szydłowcu”, Studia z Dziejów Rzemiosła i Przemysłu 4 (1964): 56; „Herbek, Jan”, w Marta Pieniążek-Samek, Kielce XVII-XVIII wiek. Słownik biograficzny (Kielce: Wydawnictwo Akademii Świętokrzyskiej, 2003), 60.

32 „Murarze”, w Zygmunt Gloger, Encyklopedia staropolska ilustrowana, t. 3 (Warszawa: Druk. P. Laskauera i S-ki, 1902), 239; Dumała, „Przyczynek”, 56.

33 Marta Pieniążek-Samek, „Nieznane źródło do badań nad pałacem biskupów krakowskich w Kielcach”, Rocznik Muzeum Narodowego w Kielcach 21 (2003): 75-76; Marta Pieniążek-Samek, Tributum gratitudinis reddo. Fundacje artystyczne na terenie Kielc w XVII i XVIII wieku. Studium z historii kultury (Kielce: Kieleckie Towarzystwo Naukowe, 2005), 165, 169. 


\section{Aneksy źródłowe}

Aneks 1

Kontrakt między Janem Działyńskim a Janem Herberkiem na budowę kościoła jezuickiego w Grudziądzu z dnia 2 VIII 1646 r.

Archiwum Państwowe w Toruniu, Akta klasztoru OO. Jezuitów w Grudziądzu, sygn. 5, s. 49-50.

Stało się postanowienie między Wielmożnym Jegomością Panem Janem z Działynia Działyńskim, Puckim, Rogozińskim, Pokrzywnickim Starostą $\mathrm{z}$ jednej strony, a Panem Janem Herberkiem, kłodawskim mieszczaninem, architektem z drugiej. Wielmożny Jegomość Pan Starosta Pucki za wymurowanie kościoła, zakrystyiei, sklepiku do zakrystyiei należącego, w Grudziądzu ojcom Societatis Jesu ma dać piętnaście tysięcy złotych polskich, za wszystką robotę rachując. Który kościół będzie długi na czterdzieści łokci, a szeroki między filarami rachując na szesnaście łokci. A ten kościół ma wystawić pomieniony Pan Architekt przez dwie lecie, według wizerunku podanego. Materyię będzie powinien Jegomość Pan Starosta Pucki dawać, według potrzeby, tak cegły, kamienia, wapna, piasku, wody, rusztowania, jako i ankier ${ }^{1}$ żelaznych i drzewnianych dębowych, krokiew, tarcic, krat do okien, gdzie potrzeba, zawias, haków, łat narzezanych wysuszonych, bratnalów ${ }^{2}$, in summa materyiei zależącej wszelakiej, tak do kościoła, jako i zakrystyiei i sklepiku jej. A wczas ma opatrzyć Jegomość cieślę do wiązowania dachu i drzewa do niego, aby kiedy kościół stanie w murze zaraz cieśla gotowe stawiał wszystko wiązanie suche. A jeżeliby Jegomość Pan Starosta chciał mieć co z ciosanego kamienia, jako kapitele, bazy i w facjacie odrzwi i gzemsy, tedy tego wszystkiego ma dodać Jegomość, żeby wyrobione kamienie w Grudziądzu stawiono. A jeśliby nie chciał, to się cegłą wszystkie te rzeczy wymurują. Pieniędzy z potrzebą da Jegomość Pan Starosta, żeby była summa gotowa u księdza starszego grudziądzkiego Societatis Jesu, aby omieszkanie w zapłacie czela-

W edycji kontraktów zastosowano się do zaleceń instrukcji wydawniczej - Kazimierz Lepszy, red., Instrukcja wydawnicza dla źródeł historycznych od XVI do połowy XIX wieku (Wrocław: Ossolineum, 1953). Mając na względzie przejrzystość tekstu, pojawiające się w dokumentach popularne skróty rozwiązano bez użycia nawiasów - te zastosowano tylko przy mniej oczywistych skrótach oraz literach opuszczonych w rękopisie. Pominięto również wyrazy skreślone.

Ankier - klamra spinająca mury.

2 Bratnal-gwóźdź. 
dzi żadne nie było. Al[b]owiem za dostatkiem materyiei przybrać się może więcej czeladzi, aby fabryka prędzej poszła. Co bez pieniędzy gotowych być nie może. Pan Jan Architekt z swej strony ma pilnować, aby gruntownie fundamenta zakładał, żeby szkoda nie była. Bo gdyby się miało rysować sam Pan Architekt powinien będzie temu zabieżeć. Czeladzi co kielnią robią, także i pomocnikom on będzie płacił. Robota ma być piękna, według abrysu podanego ścian. Ma pilnować Pan Architekt tego, żeby fabryka nie wakowała i jako na[j]prędzej do góry szła. Tenże kościół ma Pan Architekt dachówką pokryć olenderską, którą spadkiem ma podflikować ${ }^{3}$. Będzie powinien tenże Pan Architekt grobów w kościele wymurować sześć, dwa w małym chórze, a cztery w wielkim. Sklepiste wszystkie mają być. Wszystek kościół ma [s. 50] potynkować, wybielić i żełowanie ${ }^{4}$ na sklepieniu piękne uczynić. Naczynie wszelakie mularskie do muru powinien Pan Architekt opatrzyć z linami potrzebnymi. Wysokość tego kościoła krom dachu ma być na dwadzieścia cztery łokci. Na co się dla lepszej wiary oboja strona podpisała z przyciśnieniem pieczęci. W Pokrzywnie 2 augusti millesimo sexcentessimo quadragesimo sexto.

Jan Działyński mp

Jan Herberk miesczan[in] kłodawski mp

2 augusti, na którą robotę biorę zadatku złotych dwieście

[Poniżej kilka notatek rozliczeniowych, $w$ dużej mierze nieczytelnych. Ostatnia zarejestrowana wypłata z 15 IX $1647 r$.]

Aneks 2

Kontrakt między Władysławem Konstantym Wituskim a Janem Herberkiem na prace remontowe w zamku $w$ Rogóźnie z dnia 1 VII 1647 r.

Riksarkivet, Stockholm, Skoklostersamlingen, sygn. E8602. Dostęp 20 września 2016, http://www.repcyfr.pl/dlibra/doccontent?id=997\&dirids $=1$.

Stało się pewne postanowienie z Jegomością Panem Władysławem Konstantym na Zycku Wituskim, chorążym gostyńskim, starostą rogozińskim,

3 Podflikować - uzupetnić, załatać (od niem. flicken).

4 Żyłowanie - żebra sklepienne. 
dworzaninem pokojowym Jego Królewskiej Mości. O tym, iż Jegomość na reformację Zamku Rogozińskiego ze mną, Janem Herberkiem, magistrem rzemiosła mularskie $[g]$, uczynił postanowienie w ten sposób. Naprzód ma tę stronę, na którą abrys jest podany według miary, ma ten magister wystawić, to jest jeżeliby się jaka ruina pokazała pod tą częścią w piwnicach, tedy on powinien zabieżeć i naprawić słusznie. Nad piwnicami w drugim gmachu także pierwszego piętra, kędy kuchnia ma być, powinien kędy potrzeba porządnie poprawić, jako frambugi, które są nadwątlone rozebrać, buxtele ${ }^{1}$ podwlec i zasklepić, miejscami kędy mur jest zepsowany i od wody wyciekł naprawić. Okna w tych budynkach na miejscach swoich, to jest nad piwnicami wyłamać, ile ich będzie potrzeba wyciągała i porządnie robotą chędogą wyprawić. Drzwi postawić, to jest futra we drzwiach dlia słusznego zawarcia tych budynków. Kuchnia pod stołową izbą ma zrobić, do komina gotowego, który murem idzie jako najlepiej będzie rozumiał, ale raczej przy dolnej, aby sposobna była, żeby w izbie stołowej nie zawadzała. Także ma murem przegrodzić żeby sień i izdebka kuchenna była. Przegrodę wziąwszy z muru piwnicznego ma uczynić w budynku nad piwnicami i tę ścianę prowadzić aż do góry budynków wierzchnich. Kominy, fundamenta, podpiece ${ }^{2}$, okna, drzwi wyłamać w miejscach swoich i porządnie wyprawić robotą chędogą. Posadzkę w pokojach położyć, dachówkę na tymże gmachu jako wizerunek podaje, jakakolwiek dachówka będzie powinien ją położyć. Alkierzów dwa na rogach, także porządnie robotą mularską oddać. Na wieży, na wielkiej, iż dachówka popsowana powinien ją naprawić. Owo in summa według abrysu podanego powinien tę robotę oddać. A Jegomość Pan mój Dobrodziej miłościwy rumy³, które są w pierwszym piętrze i drugim, także i w piwnicach poddanymi swoimi kazać wyrumować ${ }^{4}$ grunty [s. 2] jeżeliby kędy potrzeba wyciągała ma Jegomość także swoim kosztem kazać wykopać. Ciesielska robota jako balki, wiązanie aby omieszkania nie było tą robotą wygodzić, futra do drzwi drzewiane kazać zawczasu porobić albo też i zamienne dać, aby część jedna przed zimą pokojów tych mogła się zawrzeć, materiei należącej do tej roboty ma Pany Dobrodziej mój Miłościwy dodać należący, to jest cegły, wapna, piasku, wody, krokiew do rosztowania, tarcic do rosztowania i do buxteli, bratnali, ankier tak drzewianych, jako żelaznych ile ich trzeba będzie wyciągała dodać,

Buksztel - pomocnicza konstrukcja podporowa, stosowana przy budowie sklepień, łuków.

Podpiece - kominki.

Rum - gruz.

Wyrumować - wyprzątnąć. 
także blach do kominów izdebnych. In summa należącej materiei Pan mój Dobrodziej miłościwy ma kazać dodać. Wschód ${ }^{5}$ wielki murowany, w którym miejsca Ichmością będzie się podobało według abrysu podanego ma zmurować i porządnie oddać. Od której roboty ma mu dać Jegomość pieniędzy monety lidzby polskiej florenów

Przy tym legumina żyta, której 10

Pszenicę której 4

Jęczmienia której $\quad 4$

Piwa b[eczek] 6

Masła fasek 2

Gomółek kop 2

Słoniny połci 2

Baranów 3

Soli korzec 1

Jarzyn, to jest kapusty, pasternaku, marchwi

Na post rybek miasto śledzi

Działo się w Zamku Rogozińskim die 1 juli anno 1647

Jan Herberk mieszczan[in] kłodawski mp

\section{Bibiografia}

Materiały archiwalne

Riksarkivet, Stockholm, Skoklostersamlingen, sygn. E8602 [Kontrakt między Władysławem Konstantym Wituskim a Janem Herberkiem na prace remontowe w zamku w Rogóźnie z 1.07.1647 r.]. http://www.repcyfr.pl/dlibra/doccontent?id=997\&dirids=1. Dostęp 20 września 2016.

Archiwum Państwowe w Toruniu, Akta klasztoru OO. Jezuitów w Grudziądzu, sygn. 5, s. 49-50, Kontrakt z architektem na fabrykę kościoła grudziądzkiego Societatis Jesu Anno Domini 1646.

Archiwum Państwowe w Toruniu, Akta miasta Torunia, kat. II, sygn. XIV-37 [Opis dóbr ekonomii rogozińskiej z 1675 r.].

Archiwum Diecezjalne we Włocławku, Akta metrykalne, Kłodawa, sygn. 1b [Spis chrztów z lat 1656-1684 oraz ślubów z lat 1668-1678 i 1684].

5 Wschód-schody. 


\section{Druki i opracowania}

Bodniak, Stanisław. „Działyński, Jan”. W Polski słownik biograficzny. T. 6, 83-84. Kraków: PAU; Wrocław: Ossolineum, 1948.

Boguwolski, Ryszard, i Lothar Hyss. Zamki krzyżackie powiatu grudziądzkiego. Grudziądz: Muzeum, 2004.

Boguwolski, Ryszard, i Andrzej Kola. Zamek pokrzyżacki w Rogóźnie. Rogoźno: Urząd Gminy; Grudziądz: Muzeum, 1997.

Brykowski, Ryszard, i Teresa Żurkowska. „Powiat grudziądzki”. W Katalog zabytków sztuki w Polsce. T. 11, z. 7. Warszawa: IS PAN, 1974.

Chrzanowski, Tadeusz. Grudziądz. Warszawa: „Sport i Turystyka”, 1970.

Chrzanowski, Tadeusz, i Marian Kornecki, „Powiat wąbrzeski”. W Katalog zabytków sztuki $w$ Polsce. T. 11, z. 19. Warszawa: IS PAN, 1967.

Czapliński, Władysław. „Władysław Konstanty Wituski, żołnierz kolonialny w XVII w.” Rocznik Gdański. Organ Towarzystwa Przyjaciół Nauki i Sztuki w Gdańsku 11 (1937): 163-176.

Dumała, Krzysztof. „Przyczynek do dziejów kamieniarstwa w Szydłowcu”. Studia z Dziejów Rzemiosła i Przemysłu 4 (1964): 53-61.

Froelich, Xaver. Geschichte des Graudenzer Kreises. T. 1 Die allmälige Gestaltung der Grundverhältnisse und Besitzrechte, die Entstehung, Bevölkerung, Verwaltung und Zusammengehörigkeit der Kreis-Ortschaften, die Entwicklung des städtischen und ländlichen Kommunalwesens, der Adelsrechte, des Steuer-, Militair-, Kirchen- und Schulwesens und der Justizverfassung. Graudenz: Selbstverlage, 1868.

Herbarz polski Kaspra Niesieckiego S.J. Powiększony dodatkami z poźniejszych autorów, rękopismów, dowodów urzędowych, wyd. Jan Nepomucen Bobrowicz. T. 3. Lipsk: nakładem i drukiem Breitkopfa i Hærtela, 1839.

„Herbek, Jan”. W Marta Pieniążek-Samek, Kielce XVII-XVIII wiek. Słownik biograficzny, 60. Kielce: Wydawnictwo Akademii Świętokrzyskiej, 2003.

Janiszewska-Mincer, Barbara. „Grudziądz w latach 1064-1772”. W Dzieje Grudziądza. T. 1 Do roku 1920, red. Jerzy Danielewicz, 190-272. Grudziądz: Grudziądzkie Towarzystwo Kultury, 1992.

Kiryk, Feliks. „Przyczynki do dziejów Szydłowca w pierwszej połowie XVII stulecia”. W Cała historia to dzieje ludzi... Studia z historii społecznej ofiarowane profesorowi Andrzejowi Wyczańskiemu w 80-tą rocznicę urodzin i 55-lecie pracy naukowej, red. Cezary Kukla, 241-254. Białystok: Wydawnictwo Uniwersytetu w Białymstoku, 2004.

Lepszy, Kazimierz, red. Instrukcja wydawnicza dla źródeł historycznych od XVI do połowy XIX wieku. Wrocław: Ossolineum, 1953.

Makowski, Bolesław. Sztuka na Pomorzu: jej dzieje i zabytki. Toruń: Kasa im. Mianowskiego; Warszawa: Instytut Popierania Nauki, 1932.

Manstein, Hugo, red. Die Annalen der Stadt Graudenz von 1563 bis 1660. Graudenz: Gustav Röthes Buchdruck, 1904. 
„Murarze”. W Zygmunt Gloger, Encyklopedia staropolska ilustrowana. T. 3, 238-239. Warszawa: Druk. P. Laskauera i S-ki, 1902.

Pabian, Andrzej, i Waldemar Rozynkowski. Zamki krzyżackie na ziemi chełmińskiej. Toruń: Wydawnictwo Naukowe „Scriptor M\&A”, 1997.

„Pade, Jan”. W Encyklopedia wiedzy o jezuitach na ziemiach Polski i Litwy 1564-1995, oprac. Ludwik Grzebień przy współpr. zespołu jezuitów, 488. Kraków: Wydawnictwo WAM, 2004.

Paliušytė, Aistè. „Fodyga, Casper“. W Allgemeines Künstlerlexikon. Die bildenden Künstler aller Zeiten und Völker. T. 41, 436-437. München-Leipzig: K. G. Saur, 2004.

Pieniążek-Samek, Marta. „Nieznane źródło do badań nad pałacem biskupów krakowskich w Kielcach”. Rocznik Muzeum Narodowego w Kielcach 21 (2003): 73-77.

Pieniążek-Samek, Marta. Tributum gratitudinis reddo. Fundacje artystyczne na terenie Kielc w XVII i XVIII wieku. Studium z historii kultury. Kielce: Kieleckie Towarzystwo Naukowe, 2005.

Poraziński, Jarosław. „Działyński, Jan”. W Słownik biograficzny Pomorza Nadwiślańskiego. T. 1, 366. Gdańsk: Wydawnictwo Gdańskie, 1992.

Rzeczkowska-Sławińska, Maria. „Zamek pokrzyżacki w Rogoźnie (powiat grudziądzki)”. Rocznik Grudziądzki 5-6 (1970): 71-96.

„Siekierzecki, Daniel”. W Encyklopedia wiedzy o jezuitach na ziemiach Polski i Litwy 1564-1995, oprac. Ludwik Grzebień przy współpr. zespołu jezuitów, 615. Kraków: Wydawnictwo WAM, 2004.

Umiński, Janusz. Grudziądz. Przewodnik. Warszawa: „Sport i Turystyka”, 1974.

„Wituski, Władysław Konstanty”. W Zdzisław Malczewski, Słownik biograficzny Polonii brazylijskiej, 202. Warszawa: Centrum Studiów Latynoamerykańskich - Uniwersytet Warszawski, 2000.

Załęski, Stanisław. Jezuici w Polsce. T. 4, cz. 3 Kolegia i domy założone w drugiej dobie rzadów Zygmunta III i za rząów Władysława IV: 1608-1648. Kraków: Druk. W. L. Anczyca, 1905.

Zawadka, Agnieszka. „Nowożytne zabytki epigraficzne kościoła pw. św. Franciszka Ksawerego w Grudziądzu”. Rocznik Grudziądzki 15 (2003): 221-231. 